\title{
THE SUPERIOR ORDERS DEFENCE: A GAME OF MUSICAL CHAIRS AND THE JURY IS STILL OUT
}

\author{
Jackson Nyamuya Maogoto*
}

\section{INTRODUCTION}

The enforcement of modern international humanitarian law dates back to the Middle Ages, when the first known war crimes trials were held. ${ }^{1}$ The first criminal tribunal to bring to justice someone responsible for war crimes occurred in 1474 when an ad hoc supranational criminal tribunal composed of 28 judges from different states allied to the Roman Empire, tried Peter Von Hagenbach for murder, rape, perjury and other crimes in violation of 'the laws of God and man' (what would today be characterised as crimes against humanity) during his occupation of the town of Breisach on behalf of Charles, the Duke of Burgundy. ${ }^{2}$ In the first recorded modern use of the superior orders defence Peter von Hagenbach, Governor of Breisach, unsuccessfully raised the defense. ${ }^{3}$ He was convicted and sent to the gallows.

In 1618, internal and continental religious and political decay in Europe erupted in what would soon become a Thirty years war lasting till 1648. The war was to shatter the Respublica Christiana the 'international order' founded upon natural law, which had endured for a thousand years since the collapse of the Roman Empire, but had

\footnotetext{
* LL.B (Hons) (Moi), LL.M (Hons) (Cantab), PhD (Melb), GCertPPT (UoN), Senior Lecturer University of Newcastle, School of Law (Australia).

${ }^{1}$ : M Cherif Bassiouni, International Criminal Law (1987) 3-4.

${ }^{2}$ For a short account of this trial and references to other accounts, see George Schwarzenberger, International Law as Applied by Courts and Tribunals (1968) 462-6.

${ }^{3}$ Ibid.
} 
withered in the face of the onslaught of the Renaissance and the Reformation. ${ }^{4}$ During the course of the Thirty Years War, in 1625, Hugo Grotius, a pre-eminent publicist (acclaimed as the Father of International Law), published his seminal work De Jure Belli ac Pacis Libris Tres. ${ }^{5}$ In it, Grotius insisted that war should be governed by a strict set of laws. ${ }^{6}$ Grotius maintained that violence beyond that necessary to secure the military goal was not justified, and that suffering should be minimised within the parameters of military requirements. ${ }^{7}$ In his seminal work, Grotius also addressed the subject of superior orders noting that '[i]f the authorities issue any order that is contrary to the law of nature or to the commandments of God, the order should not be carried out. ${ }^{, 8}$

A year after the end of the Thirty Years War, Daniel Axtell, Captain of the Parliamentary Guard at the capital trial and execution of King Charles I, bullied and beat the soldiers under his command to make them cry for 'justice' and 'execution', and encouraged his men to barrack the King when he tried to speak in his own defence. ${ }^{9}$ About a decade later, in 1660, Colonel Axtell was brought to trial for his actions as a regicide. In his defence he asserted that he was only obeying orders. ${ }^{10}$ His reliance on the superior orders defence was unsuccessful. Like Hagenbach two centuries earlier, he was sent to the gallows.

\footnotetext{
${ }^{4}$ This was in the form of two treaties signed in the Westphalian towns of Munster and Osnabruck. However from the legal point of view, the two treaties were considered as a single instrument.

${ }^{5}$ Hugo Grotius, The Rights of War and Peace: Including the Law of Nature and of Nations, (A C Campbell trans, 1901).

${ }^{6}$ Ibid vol 3, 323-3, 359-64; Quincy Wright, A Study in War (1965) 872-5.

${ }^{7}$ Grotius above n 5, vol 3, 328-30.

${ }^{8}$ Hugo Grotius, The Law of War and Peace (Francis W Kelsey trans, 1925) vol 2, 138.

${ }^{9}$ An Exact and Impartial Accompt Of the Indictment, Arraignment, Tryal, and Judgment (according to Law) of Twenty Nine Regicides, The Murtherers of His Late Sacred Majesty Of Most Glorious Memory (1660).

${ }^{10}$ A Report of Divers Cases in Pleas to the Crown (1708) 84 ER 1055, 1060 (commenting on the trial of Axtell).
} 
As ancient as the laws of war are, soldiers charged with violating them have over the centuries raised obedience to orders as a defense. The defence of superior orders has been embraced in a bid to balance the competing aims of promoting discipline in the military while not entirely subverting humanitarian standards. The superior orders defence is underpinned by the intent and knowledge standard i.e. was the perpetrator aware that his/her conduct was unlawful. However it is this very aspect that has been central to the fluidity of the superior orders defence over the last four centuries. Over time the divide between the national and international approaches has solidified. A survey of national law shows a bias towards accepting the defence as automatic and complete. This is no doubt aimed at cementing military discipline which is built on 'total and unqualified obedience [to orders] without any hesitation or doubt'. ${ }^{11}$ On the other hand, the standard in supranational criminal tribunals tends towards an absolute liability rule which only provides for a very limited use of the order as a mitigating circumstance.

The international standard was encapsulated in the Nuremberg Charter which explicitly provided that a perpetrator cannot claim absence of guilty knowledge based on his or her ignorance of the illegality of the superior orders upon which he or she executed the act, if he or she in any event approved what had to be done. ${ }^{12}$ However, despite the seemingly clear international standard espoused by the Nuremberg and Tokyo Charters and cemented by dozens of post World War II cases, the international standard failed to penetrate and influence the national standard. This was evident in 1977 during negotiations to formulate the Additional Protocols to the 1949 Geneva

\footnotetext{
${ }^{11}$ See Yoram Dinstein, 'The Defense of "Obedience to Superior Orders"' (1965) 19 International Law 5 (quoting Military Prosecutor v Melinki (1957) 17 Pesakim (D) 90, 213 (Israel)).

${ }^{12}$ Trial of Otto Ohlendorf \& Others, cited in United States $v$ Wilhelm List \& Others (The Hostage Cases) (1949) 8 Trials Of War Criminals Before The Nuerenberg Military Tribunal Under Control Council Law No. 10 34, 91.
} 
Conventions. Majority of the countries were opposed towards adopting the international standard. Despite lengthy negotiations to draft a provision limiting the defense of superior orders, the effort was unsuccessful due to vociferous objections by majority of the States, the argument being that that the proposed provision did not adequately balance humanitarian law with military discipline and were keen to ensure military discipline by offering their soldiers full immunity. Two decades after the wrangle over the Protocols, in 1998 the national standard received a boost and the international standard took a battering. In a surprise twist the Rome Statute for an International Criminal Court allowed a limited form of the defence.

This article has as its aim an exploration of the development of the superior orders defence within both the national and international arena. It will carry out a discussion of the case law at both the national and international level as well as discuss various legal provisions as encapsulated in international instruments and national military manuals. It wraps up with a n overview of the military and international law paradox. On one hand, military law tutors and trains soldiers to comply with commands in order to insure organisational integrity and efficiency, on the other hand international law seems to suggest by the tenor of its standard that soldiers should stop and consider the lawfulness of their orders.

\section{THE ENSHRINEMENT OF A ForgIVING STANDARD: THE ANGLO-AMERICAN POSITION}

In 1906 in his seminal and influential treatise 'International Law', Professor Oppenheim, a Cambridge scholar was to shape the Anglo-American position for the next four decades by laying down the bedrock for a concrete and definitive Anglo- 
American military standard. In his work, Oppenheim postulated that the obedience to superior orders constituted a complete and absolute defense to criminal prosecution.

In this regard he asserted clearly and forcefully that:

If members of the armed forces commit violations by order of their Government, they are not war criminals and cannot be punished by the enemy... In case members of forces commit violations ordered by their commanders, the members cannot be punished, for the commanders are alone responsible... ${ }^{13}$

His formulation was based

on an interpretation of then traditional concepts of international law which [interwove] obedience to orders with respondeat superior and its related Act of State Doctrine. In doing so, Oppenheim was instrumental in bringing about a sea change to the soldiers' obedience defense. $^{14}$

Oppeinheim's articulation of the standard was codified about five years later in the leading military manual of the time when he wrote Great Britain's 1912 handbook on the rules of land warfare. This standard (which the Americans would soon incorporate) was to endure for the next four decades. In the handbook, Oppenheim incorporated his dicta that, for subordinates, obedience to orders constituted a complete defense to violations of the law of war. Article 443 of the British manual provided that members of the armed forces who violated the recognised rules of war in compliance with the orders of their government or commander 'are not war criminals and cannot therefore be punished by the enemy. ${ }^{15}$ Superior orders was a complete defence for subordinates with superiors liable under the doctrine of command responsibility.

Two years after Britain's Manual, America published its first manual relating to the law of war. In a break with its traditional position, the American handbook dutifully

\footnotetext{
${ }^{13}$ Lassa Oppenheim, International Law: A Treatise (1st ed, 1906) 264-5.

${ }^{14}$ Gary D Solis, 'Obedience of Orders and the Law of War: Judicial Application in American Forums' (1999) 15 American University International Law Review 481, 494.

${ }^{15}$ George A Finch, 'Superior Orders and War Crimes' (1921) 15 American Journal of International Law 440, 441.
} 
encapsulated Oppenheim's dicta moving firmly to align itself with the centuries old British position. ${ }^{16}$ Article 443 of the British handbook provision was echoed in Article 336 of the Rules of Land Warfare approved by the General Staff of the United States Army. ${ }^{17}$ In this regard the American handbook provided that:

[I]ndividuals of the armed forces will not be punished for these offenses in case they are committed under the orders or sanction of their government or commanders. The commanders ordering the commission of such acts... may be punished by the belligerent into whose hands they may fall. ${ }^{18}$

While the United States manual stated that officers ordering illegal acts 'may be punished', the following phrase, 'by the belligerent into whose hands they may fall', suggests that, should the officer never be captured, or should he be of the ultimately victorious army, any punishment at all would be problematic. Though the AngloAmerican position at the start of $20^{\text {th }}$ century was definite that superior orders was an automatic and complete defence, in continental Europe, however, the position that the defence of superior orders was not an automatic nor complete continued to prevail. The continental Europe position is encapsulated in Article 47 of the German Military Penal Code of $1872 .{ }^{19}$ This provided that the superior issuing an order was alone responsible. ${ }^{20}$ However, a subordinate was to be punished as an accomplice in the event that he 'went beyond the order given to him' or 'knew that the order of the superior involved an act which aimed at a civil or military crime or offense'. ${ }^{21}$ The Germans never wavered from this position, and it was still the operative legal

\footnotetext{
${ }^{16}$ See Donald A Wells, The Laws of Land Warfare: A Guide to the U.S. Army Manuals (1992) 5.

${ }^{17}$ Finch, above n 15, 441.

${ }^{18}$ See Wells, above n 16, 118 (quoting paragraph 366 of the 1914 version of The Rules of Land Warfare).

${ }^{19}$ See N C H Dunbar, 'Some Aspects of the Problem of Superior Orders in the Law of War' (1951) 63 Juridical Review 234, 244.

${ }^{20}$ Ibid.

${ }^{21}$ Ibid.
} 
principle three decades later during World War I and remained so up to and including World War II.

The Article now turns to discuss World War I. The war was significant in offering an avenue for the entry onto the international agenda of the superior orders defence. The Paris Conference, the centrepoint of the post-World War I push by the victorious Allies to create a new world order, spawned the Allied Commission on the Responsibility of the War and on the Enforcement of Penalties (Allied Crimes Commission) and the first major effort to curb international crimes through international penal process. This Commission was to grapple with the defence of superior orders for the first time at the international level and in a significant effort herald the international position - the preclusion of the defence as an automatic and complete defence. This stance was at odds with the military manuals of many states, however it favoured the continental Europe stance over the Anglo-American position.

\section{A The Peace Treaty of Versailles: Superior Orders Gets onto the International Agenda}

In 1914, Europe, divided by competing military alliances, was a powder keg waiting to explode. The fuse was lit when a Serbian nationalist assassinated Austrian Archduke Franz Ferdinard on the bridge at Sarajevo. Lacking any institution with authority to maintain peace, the disputing parties had no choice but to call upon their allies and resort to force. The war saw the maturation of the concept of total war and shocking atrocities. Amidst the war, the observations of Oppeinheim as encapsulated in the British and American manuals found strong support and defence in Sir Graham Bower, a career soldier and former naval commander. In a talk before the English 
Grotius Society in 1915, he endorsed Oppenheim's view as emblematic of prevailing international law doctrine. ${ }^{22}$ Bower condemned as cruel and inhumane the then German submarine fleet's attacks on merchant vessels under circumstances in which it was impossible to save the passengers and crew. ${ }^{23}$ He stressed that according to prevailing military law 'the blame does not rest with them [submarine commanders], but with their superiors'. ${ }^{24} \mathrm{He}$ concluded that holding a subordinate officer 'responsible is to strike at the foundations of discipline in every army or navy in the world'. ${ }^{25}$

However, there was emerging unease with the Oppenheim standard. In 1918 the Birkenhead Committee of Enquiry on War Crimes, established by the British government, disputed the statement that a subordinate should never question an order. The committee recommended that the plea of superior orders should not be applied by courts which might be established to prosecute German war criminals in those cases in which acts were 'flagrantly' and 'obviously' contrary to the laws of war. ${ }^{26}$ However the recommendation of the Committee was dead without mourners or honour and the Oppeinheim standard was to reign supreme for another three decades.

In March 1919, the Allied Crimes Commission reported that 'military authorities cannot be relieved from responsibility by the mere fact that a higher authority might have been convicted of the same offense' ${ }^{27}$ The Commission declared that the courts

\footnotetext{
${ }^{22}$ Graham Bower, 'The Laws of War: Prisoners of War and Reprisals' (1916) 1 Transactions of the Grotius Society 15, 24.

${ }^{23}$ Ibid.

${ }^{24}$ Ibid.

${ }^{25}$ Ibid 24-5.

${ }^{26}$ See Dunbar, above n 19, 243.

${ }^{27}$ See Commission on the Responsibility of the Authors of the War and on Enforcement of Penalties, 'Report Presented to the Preliminary Peace Conference' (1920) 14 American Journal of International Law 95, 117 (describing the creation and composition of the Commission). The Commission was
} 
would determine whether a plea of superior orders was sufficient to acquit the person charged. ${ }^{28}$ After much compromise, the representatives on the Allied Crimes Commission finally agreed on the terms of the Treaty of Peace between the Allied and Associated Powers and Germany ('Peace Treaty of Versailles'), concluded at Versailles on 28 June $1919 .^{29}$ Besides other important matters including reparations, the treaty in Article 227 provided for the creation of an ad hoc international criminal tribunal to prosecute Kaiser Wilhelm II for initiating the war. ${ }^{30}$ It further provided in Articles 228 and 229 for the prosecution of German military personnel accused of violating the laws and customs of war before Allied Military Tribunals or before the Military Courts of any of the Allies. ${ }^{31}$

Contrary to the British and American manuals of the day, Article 228 evinced the collective intention of the Allies to apply individual responsibility for law of war violations, without regard for the defense of superior orders. Professor James W.

composed of fifteen members, two each from the United States, the British Empire, France, Italy, and Japan, and the other five members elected from the powers with special interests.

${ }^{28}$ Ibid.

${ }^{28}$ Ibid.

${ }^{29}$ Treaty of Peace between the Allied and Associated Powers and Germany, opened for signature 28 June 1919, [1920] ATS 1 (entered into force 10 January 1920) ('Peace Treaty of Versailles')

${ }^{30}$ Peace Treaty of Versailles, opened for signature 28 June 1919, [1920] ATS 1, art 227 (entered into force 10 January 1920).

${ }^{31}$ See Peace Treaty of Versailles, opened for signature 28 June 1919, [1920] ATS 1 (entered into force 10 January 1920). Art 228 states:

The German Government recognizes the right of the Allied and Associated Powers to bring before military tribunals persons accused of having committed acts in violation of the laws and customs of war. Such persons shall, if found guilty, be sentenced to punishments laid down by law. This provision will apply notwithstanding any proceedings or prosecution before a tribunal in Germany or in the territory of her allies.

The German Government shall hand over to the Allied and Associated Powers, or to such one of them as shall so request, all persons accused of having committed an act in violation of the laws and customs of war, who are specified either by name or by the rank, office, or employment which they held under the German authorities.

Art 229 states:

Persons guilty of criminal acts against the nationals of one of the Allied and Associated Powers will be brought before the military tribunals of that Power. Persons guilty of criminal acts against the nationals of more than one of the Allied and Associated Powers will be brought before military tribunals composed of members of the military tribunals of the Powers concerned. In every case the accused will be entitled to name his own counsel. 
Garner, a leading international law scholar of the period, commented on the new frontiers that the Article had broken:

[Article 228] appears to be the first treaty of peace in which an attempt has been made by the victorious belligerent to enforce against the defeated adversary the application of the principle of individual responsibility for criminal acts during war by members of his armed forces against ... the other party. ${ }^{32}$

By 1920, the Allies had compiled a list of approximately 20,000 Germans who were to be investigated for war crimes. ${ }^{33}$ These crimes included torture, use of human shields, rape, and the torpedoing of hospital ships by German submarines. ${ }^{34}$ By 1921 when the provisions finally got a realistic chance for implementation, the zest of the Allies to set up joint or even separate military tribunals had waned, and new developments in Europe required that Germany not be further humiliated. While there is no question that these terrible crimes were covered by the international law of armed conflict as it then existed, the Allies were apprehensive of trying so many German officials and personnel as this posed a political problem for the Allies. ${ }^{35}$ An alternative solution was therefore proposed. Instead of setting up an international tribunal, Germany would conduct the prosecutions. An agreement was thus made, allowing the German government to prosecute a limited number of war criminals before the Supreme Court of Germany (Reichsgericht) in Leipzig instead of establishing an Allied Tribunal, as provided for in Article 228.

\footnotetext{
32 James W Garner, 'Punishment of Offenders Against the Laws and Customs of War' (1920) 14 American Journal of International Law 70, 70-1.

${ }^{33}$ M Cherif Bassiouni, 'Former Yugoslavia: Investigating Violations of International humanitarian Law and Establishing an International Criminal Tribunal' (1995) 18 Fordham International Law Journal $1191,1194$.

${ }^{34}$ James F Willis, Prologue To Nuremberg: The Politics and Diplomacy of Punishing War Criminals of the First World War (1982) 137-9.

${ }^{35}$ Germany was trying to reconstruct and the Allies were apprehensive that extensive trials of such a large number of military personnel might jeopardise the stability of the already vulnerable Weimar Republic and expose it to revolutionary Bolshevik influence: ibid 113.
} 
In response to the Allied request to undertake prosecutions, Germany, which had previously passed a national law to implement provisions of Articles 228 and 229 of the Peace Treaty of Versailles, passed new legislation to assume jurisdiction under its national laws in order to prosecute accused offenders before its Supreme Court, sitting at Leipzig as a way of placating public opinion in the Allied countries. ${ }^{36}$ Of this trials, two notable involved the defense of superior orders. In the Case of Lieutenant Karl Neumann, the German commander of a German submarine, admitted that he had torpedoed and sunk the British hospital ship, Dover Castle, but pleaded that he did so only in obedience to orders issued by the Admiralty. ${ }^{37}$ The German Supreme Court held that Neumann believed the order to be a lawful reprisal, as the order specified, and therefore was not personally responsible for the sinking of the Dover Castle. ${ }^{38}$ Applying the German military standard in regard to superior orders defence, the German Supreme Court acquitted Neumann. ${ }^{39}$ The judgment was clearly based on the lack of knowledge of the manifest illegality on the part of Neumann with regard to his actions.

The Dover Castle case can be contrasted with the outcome of the trial of Lieutenants Ludwig Dithmar and Johann Boldt. The military officers were under the command of Captain Helmuth Patzig aboard the submarine U-86 which had sunk a Canadian

\footnotetext{
36 'Despite the Allied Commission's extensive report and the Allies' supplemental information conveyed to the German Procurator General, only twelve military officers were ultimately prosecuted before the Reichsgericht': M Cherif Bassiouni, 'From Versailles To Rwanda in Seventy-Five Years: The Need To Establish a Permanent International Criminal Court' (1997) 10 Harvard Human Rights Journal 11, 20.

${ }^{37}$ See 'Judgment in Case of Commander Karl Neumann, Hospital Ship "Dover Castle"' (1921) 16 American Journal of International Law 704, 708 (acquitting the defendant in the Dover Castle case and holding that the defendant had sunk the Dover Castle following orders from his highest superiors, which he considered binding, and therefore could not be punished for his conduct).

${ }^{38}$ See ibid.

${ }^{39}$ See Morris Greenspan, The Modern Law of Land Warfare (1959) 706-7.
} 
hospital ship, the Llandovery Castle. ${ }^{40}$ At trial, the evidence revealed that, just after the sinking, Captain Helmuth Patzig sought to conceal the 'misadventure' by ordering the two accused subordinates to machine-gun survivors. ${ }^{41}$ Like Neumann, Dithmar and Boldt pleaded 'not guilty' on the basis of superior orders from the German naval high command. The Court found the two officers guilty as accessories to homicide. ${ }^{42}$ In explaining its ruling, the Court stated:

According to the Military Penal Code, if the execution of an order . . . involves such a violation of law as is punishable, the superior officer issuing such an order is alone responsible. However, the subordinate obeying such an order is liable to punishment if it was known to him that the order... involved the infringement of civil or military law. This applies in the case of the accused. ${ }^{43}$

In sum, the Leipzig trials dealt exclusively with the defence of superior orders in the context of war crimes. The matter whether this defence applied to other international crimes remained open. Importantly the thrust of the Peace Treaty was towards individualising criminal responsibility for violations of laws of war and the commission of crimes against humanity. The punishment provisions of the Peace Treaty of Versailles sought to limit the scope of the principle of sovereign immunity by punishing military and civilian officials, while at the same time extending universal jurisdiction to cover war crimes and crimes against humanity. ${ }^{44}$

B World War II: Relegating the Superior Orders Defence to a Mitigating Circumstance

\footnotetext{
${ }^{40}$ See 'Judgment in Case of Lieutenants Dithmar and Boldt, Hospital Ship "Llandovery Castle"” (1921) 16 American Journal of International Law 708, 723 (holding that the subordinates were guilty, but their habit of obedience to military authority mitigated their offences).

${ }^{41}$ Ibid 714.

${ }^{42}$ Ibid 711.

${ }^{43}$ Ibid 721 (emphasis added).

${ }^{44}$ See Jackson N Maogoto, War Crimes and Realpolitik: International Justice from World War I into the $21^{\text {st }}$ Century (2003) 42-4.
} 
Amidst World War II, in 1940 the sixth edition of Oppenheim's treatise was published. The work was edited (in place of the then-deceased Oppenheim) by his successor to the Whewell Chair in International Law at Cambridge_-Professor Hersch Lauterpacht. ${ }^{45}$ The edition was a comprehensive overhaul and revision of earlier editions. With regard to the superior orders defence Lauterpacht made a significant turn around distancing himself from the standard that his predecessor's work had been instrumental in establishing. In a dramatic twist, he noted:

The fact that a rule of warfare has been violated in pursuance of an order...of an individual belligerent commander does not deprive the act in question of its character as a war crime; neither does it, in principle, confer upon the perpetrator immunity from punishment by the injured belligerent. A different view has occasionally been adopted by writers, but it is difficult to regard it as expressing a sound legal principle. ${ }^{46}$

Lauterpacht's position was premised on the central governing principle (which had found expression in continental Europe and a number of prior American and German cases) that members of the armed forces "are bound to obey lawful orders only and that they cannot therefore escape liability if, in obedience to a command, they commit acts which both violate unchallenged rules of warfare and outrage the general sentiments of humanity." ${ }^{, 47}$ Limiting liability to the individual issuing an order, in practice, may concentrate responsibility on the head of the State "whose accountability, from the point of view of both international and constitutional law, is controversial." 48

Lauterpacht's turn around did not find favour both at home and across the Atlantic. British and American military law seemed determined to cling to the earlier position espoused by Oppenheim. This is evident in the work of Clyde Eagelton, a leading

\footnotetext{
${ }^{45}$ See Lassa Oppenheim, International Law: A Treatise (Hersch Lauterpacht ed, $6{ }^{\text {th }}$ ed, 1940) $453-4$.

46 Ibid.

${ }^{47}$ See Lassa Oppenheim, International Law: A Treatise (Hersch Lauterpacht ed, $6^{\text {th }}$ rev ed, 1944) 453.

${ }^{48}$ Ibid.
} 
scholar and legal expert with the United States Department of State. Writing in 1943, he argued that it was 'repugnant' to the average person to punish subordinate soldiers who typically lacked knowledge concerning the legal propriety of their actions and risked immediate execution in the event of disobedience. ${ }^{49}$ Eagelton's views were echoed in the same year by Professor Hans Kelsen who noted the importance of discipline and unconditional obedience in military organisations and argued that in such strict structures responsibility was suitably situated in the superior officials who issued commands..$^{50}$

The following year, as World War II reached its peak and the prosecution of the excesses of the Axis Powers became an increasing reality, the sentiments of Eagleton and Kelsen supporting superior orders as an automatic defence were challenged by Professor Sheldon Glueck an international law scholar based at Harvard University. In a seminal statement supporting the prosecution of Nazi war criminals Glueck noted that the principle of non-liability in the English and American military manuals would 'render impossible' the conviction of a large number of Nazi war criminals. ${ }^{51}$ Glueck's statement echoed the standard in espoused the American cases of McDowell, Little and Mott from the previous century which had denied the superior orders defense in those instances in which a subordinate actually knew or had reasonable grounds to know of an order's illegality. ${ }^{52}$ Within a few short months Britain would revise her war manual and the position by Lauterpacht and Glueck would prevail.

\footnotetext{
${ }^{49}$ Clyde Eagelton, 'Punishment of War Criminals By the United Nations' (1943) 37 American Journal of International Law 495, 497.

${ }^{50}$ Hans Kelsen, 'Collective and Individual Responsibility in International Law with Particular Regard to the Punishment of War Criminals' (1943) 31 California Law Review 530, 556.

${ }^{51}$ Sheldon Glueck, War Criminals: Their Prosecution \& Punishment (1944) 155.

${ }^{52}$ Ibid $155-6$.
} 
Article 443 of the revised Manual text adopted almost word-for-word Lauterpacht's language. It provided that 'members of the armed forces are bound to lawful orders only and...cannot therefore escape liability, if in obedience to a command, they commit acts which, both violate unchallenged rules of warfare and outrage the general sentiment of humanity'. ${ }^{53}$ Despite having clung onto the Oppenheim standard stubbornly, seven months after the revision to the British Manual, the United States followed the British reversing and revising its Field Manual. Released on November 15,1944 , the manual incorporated a new provision providing that individuals who 'violate the accepted laws and customs of war may be punished therefor. However, the fact that the acts... were done pursuant to order of a superior or government sanction may be taken into consideration in determining culpability... ${ }^{54}$

This change in the Anglo-American standard (which re-aligned it with that of continental Europe) was no doubt driven by pragmatism. With discussions going on with regard to the trial of German and Japanese war criminals, it was practical to preclude the plea of superior orders which was clearly going to be the prevalent and dominant defence. The Anglo-American standard now mirrored the operative rule in continental Europe encapsulated in German military law which was set forth in Article 47 of the German Military Penal Code of 1872 - a subordinate was to be punished as an accomplice in the event that he 'went beyond the order given to him' or 'knew that the order of the superior involved an act which aimed at a civil or

\footnotetext{
${ }^{53}$ An Exposition of the Laws and Usage of War on Land, art 44 (1944) quoted in Guenter Lewy, 'Superior Orders, Nuclear Warfare, and the Dictates of Conscience: The Dilemma of Military Obedience in the Atomic Age' (1961) 55 American Political Science Review 3, 6 (emphasis added).

${ }^{54}$ Rules of Land Warfare, s 345.1 (1944) quoted ibid.
} 
military crime or offense'. ${ }^{55}$ In the same year, the United Nations War Crimes Commission ('UNWCC') which had been established by the Allied Powers in 1942 through an agreement at the Palace of St. James ${ }^{56}$ took up the issue of obedience to orders. Despite being composed by some of the leading international legal minds of the time, it conceded that ' $[\mathrm{t}]$ he question of individual responsibility and punishment in cases in which offenses were committed upon the orders of a... superior authority by a subordinate pledged by law to obey superior orders, is one of great difficulty'. ${ }^{57}$ In a robust reversal of the Anglo-American standard (with World War II's end in sight) that had existed for close to three decades, Justice Robert Jackson, the United States chief counsel in the prosecution of the principal Axis war criminals at Nuremberg, articulated the 'new' Anglo-American position on superior orders in a 1945 memorandum to President Franklin Delano Roosevelt. ${ }^{58}$ Jackson noted that the doctrine of immunity of heads of state typically was coupled with the superior orders defense. ${ }^{59}$ He observed that the combination of these two doctrines means that nobody is responsible insisting that modernly organised cannot tolerate so broad an area of official irresponsibility. ${ }^{60}$

\footnotetext{
55 German Military Penal Code (1872), quoted in Dunbar, above n 19, 244. A comprehensive discussion of the statutory texts is contained in Mitchell Franklin, 'Sources of International Law Relating to Sanctions Against War Criminals' (1945) 36 Criminal Law and Criminology 153, 162-8.

${ }^{56}$ St James Declaration of 13 January 1942, reprinted in Punishment For War Crimes: The Inter-Allied Declaration Signed at St James' Palace, London, on 13 January 1942, and Relative Documents (undated). See also United Nations War Crimes Commission, History of the United Nations War Crimes Commission and the Development of Laws of War (1948) 89-92. The St James Declaration was the first step leading to the establishment of the International Military Tribunal at Nuremberg.

${ }^{57}$ See The United Nations War Crimes Commission, above n 56, 274 (stating the difficulty of resolving the question of accountability of those acting on orders of a superior), 287 (noting that most defendants before the International Military Tribunal at Nuremberg pled not guilty on grounds of superior orders).

${ }^{58}$ Robert H Jackson, Report of Robert H. Jackson, United States Representative to the International Conference on Military Trials (1945) 42.

${ }^{59}$ Ibid $42,47$.

${ }^{60}$ Ibid.
} 
In the relatively short span of time from June until August of 1945, representatives of the United Kingdom, the Free French, the USSR, and the United States negotiated, drafted, and signed the Treaty of London. ${ }^{61}$ The Charter of the Tribunal was explicit that it dealt with 'offences which had no particular geographical localisation.' Article 6(a) of the Nuremberg Charter provided for crimes against peace; Article 6(b) provided for war crimes and Article 6(c) crimes against humanity. Once the procedural and legal issues were resolved, the Nuremberg Charter was appended to the London Agreement of 8 August 1945, which established the Nuremberg Tribunal. $^{62}$

Article 8 of the Nuremberg Charter addressed the superior orders defense. This provision provided that '[t]he fact that the Defendant acted pursuant to an order of his Government or of a superior shall not free him from responsibility, but may be considered in mitigation of punishment if the Tribunal determines that justice so requires ${ }^{63}$ The rejection of the superior orders defence, a key defence enshrined in most of the military manuals of the time struck directly at the standing of national law within the international arena. Though the rejection of this defence in the drafting of the Nuremberg Charter was heavily criticised, the rejection was of necessity based on the presumption of an applicable legal order outside of and beyond the Nation-State. ${ }^{64}$

\footnotetext{
${ }^{61}$ The Treaty of London includes both the Agreement for the Prosecution and Punishment of the Major War Criminals of the European Axis and the Charter of the International Military Tribunal ('Nuremberg Charter'), opened for signature 8 August 1945, 82 UNTS 280 (entered into force 8 August 1945).

${ }^{62}$ Nuremberg Charter, opened for signature 8 August 1945, 82 UNTS 280, art 8 (entered into force 8 August 1945).

${ }^{63}$ Ibid (emphasis added)

${ }^{64}$ See Katherine B Fite, The Nurnberg Judgment: A Summary (1947) 110-1.
} 
This rejection of an almost universally accepted defence in the national sphere was an important sign of the transformation of the concept.

At Nuremberg, the pageantry and chauvinism of the State was to be replaced by the solemnity and internationalism of a trial. The Nuremberg Indictment featured four counts: Count One, 'conspiracy to wage aggressive war', Count Two, 'waging an aggressive war' (or 'crimes against peace'), Count Three, 'war crimes', Count Four, 'crimes against humanity'. These counts were parcelled out between the prosecutors from the 'Big Four' Allied Powers-Robert H Jackson (United Stated), Francois de Menthon (France), Sir Hartley Shawcross (Britain) and R A Rudenko (Soviet Union). In his opening statement at Nuremberg, Justice Jackson noted that the defendants had exercised considerable discretion and power and could not credibly shift responsibility to others. ${ }^{65}$ This was echoed and buttressed further by French prosecutor Francois De Menthon who argued that orders from a superior do not exculpate defendants who carried out a 'manifest crime from responsibility. Any other solution would... be unacceptable, for it would testify to the impotence of all repressive policy'. ${ }^{66}$ Predictably, the defendants at the IMT submitted on their behalf the defence of superior orders. ${ }^{67}$ They based this on the principle of absolute loyalty to the Fuhrer's will- the principle of Fuhrerprinzip. ${ }^{68}$

\footnotetext{
65 'Opening Statement of Justice Robert H Jackson' (1947) II Trial of the Major War Criminals Before the International Military Tribunal 151.

66 'Opening Statement of M Francois De Menthon' (1948) V Trials of the Major War Criminals Before the International Military Tribunals 418.

${ }^{67}$ See generally 'Documents in Evidence at Nuremberg' (1947) I Trial Of The Major War Criminals Before The International Military Tribunal 223-4.

${ }^{68}$ See generally 'Documents in Evidence at Nuremberg' (1947) I Trial Of The Major War Criminals Before The International Military Tribunal 223.
} 
The statements by Jackson and Menthon were, however, rebuffed by one of the defense attorneys, Horst Pelckmann. Pelckmann conceded that Article 8 of the Nuremberg Charter prohibited the defense of superior orders in those instances in which a subordinate was aware of the illegal character of an order. ${ }^{69}$ However, he also insisted that the Charter must be interpreted to provide that an individual who considered that his actions were 'right and legal' should be 'exonerated'. ${ }^{70}$ Pelckmann in a spirited legal challenge to the manifest illegality standard proposed by De Menthon stated that this would lead to the illogical result that an individual who committed an illicit act without a criminal intent would not be subject to punishment. On the other hand, an individual who carried out the same act in response to a superior order would be subject to punishment by virtue of the clearly criminal character of the command. ${ }^{71}$ Pelckmann also reminded the Tribunal that a superior order may constitute compulsion and absolve a defendant from guilt. ${ }^{72}$

However in a robust riposte to Pelckmann's passionate defence, British prosecutor Sir Hartley Shawcross, in his closing statement noted that although the Charter provided that superior orders might be recognised in mitigation, ${ }^{73}$ no rule of international law accorded immunity to individuals who obeyed orders which were 'manifestly contrary to the very law of nature from which international law has grown'. ${ }^{74}$ Shawcross proclaimed that '[n]o one who chooses, as these men did, to abdicate their

\footnotetext{
${ }^{69}$ See 'Statement of Horst Pelckmann' (1948) XXI Trials of the Major War Criminals Before the International Military Tribunals 626.

${ }^{70}$ Ibid.

${ }^{71}$ Ibid.

${ }^{72}$ Ibid.

73 'Closing Statement of Sir Hartley Shawcross' (1948) XIX Trials of the Major War Criminals Before the International Military Tribunals 465.

${ }^{74}$ Ibid 466.
} 
consciences in favor of this monster [Hitler] of their own creation can complain now if they are held responsible for complicity in what their monster did' ${ }^{75}$

In its judgments, the Nuremberg International Military Tribunal rejected the defence of superior orders. 'Although entitled to do so by its Statute, the Nuremberg Tribunal refused in practice to admit the argument of superior orders in mitigation. ${ }^{76}$ In Keitel's case it said, '[s]uperior orders, even to a soldier, cannot be considered in mitigation where crimes so shocking and extensive have been committed consciously, ruthlessly, and without military excuse or justification'. ${ }^{77}$ This was echoed in the trial of Jodl: 'Participation in such crimes as these has never been required of any soldier and he cannot now shield himself behind a mythical requirement of soldierly obedience at all costs as his excuse for commission of these crimes' ${ }^{78}$ Professor Gary D. Solis, however, cautions that:

... it is not entirely correct to assert that, "[t]he IMT Charter...eliminated the defense of superior orders." As single-mindedly as the IMT Charter may have applied the element as to senior officers and officials, the IMT nevertheless did inject an ameliorating factor not suggested by a strict interpretation of the Charter: "The True Test." The IMT explained that the True Test was the inquiry not of whether there was "the existence of the [manifestly illegal] order, but whether moral choice was in fact possible." 79

The author concurs with Solis considering that despite the clear statements of the Nuremberg Court, there are certain moral and legal issues to consider-alleged illegal action after all centers on the issue of obedience versus moral choice. ${ }^{80}$ This was articulated by the Nuremberg Tribunal in the Trial of Wilhelm List. The court

\footnotetext{
75 Ibid.

${ }^{76}$ William A Schabas, 'Sentencing By International Tribunals: A Human Rights Approach' (1997) 7 Duke Journal of Comparative and International Law 461, 486.

${ }^{77}$ In Re Gsring et al., 13 Ann Dig. 536 (1946). Gsring, supra note 3, at 536.

${ }^{78}$ Nuremberg Charter, opened for signature 8 August 1945, 82 UNTS 280, art 8 (entered into force 8 August 1945).

${ }^{79}$ Gary D Solis, above n 14, 516.

${ }^{80}$ See Herbert C Kelman and V Lee Hamilton, Crimes Of Obedience (1989) ii (describing the source of superior orders as unquestioning obedience versus principled resistance).
} 
commented that in a defense of superior order: ' $[\mathrm{t}]$ he true test ... is not the existence of the order, but whether moral choice was in fact possible'. ${ }^{81}$ In any case:

In the Nuremberg Trials, the distinction between conduct crimes (general intent) and crimes where criminal liability is dependent upon the act serving as a means of bringing about certain specified consequences (special intent) was upheld, and it was there noted that the special intent required for the latter category of crimes may not be presumed as a consequence of the act but must be proved. ${ }^{82}$

In the trials before the international criminal tribunal the crimes in question were premise on war crimes, crimes against peace and crimes against humanity. In dealing with the defence of superior orders the Court was clear that they did not exonerate subordinates from personal responsibility. Considering that the Court did not explicitly draw a distinction between the three international crimes in rebutting the defence, the author avers that the unspoken position was that the defence (in its limited and diluted form as a mitigating factor) applied to all acts that a subordinate undertook in the course of their duties. This in essence means that the defence had it been available would have applied across board. The author's assertion is borne out in the subsequent national trials under the umbrella of Allied Control Council promulgated Law No. 10 ('CCL No. 10') promulgated in December 1945. It should be noted that CCL No. 10 mirrored the Nuremberg legal treatment of the superior orders defence, however in a mark of the schism that was to continue between the international and national standards, domestic war crimes trials did not endorse the Nuremberg standard-accepting that under appropriate circumstances, superior orders could be pled as a defense as well as in mitigation. ${ }^{83}$ The Article now turns to

\footnotetext{
${ }^{81}$ John D Van der Vyver, 'The International Criminal Court and the Concept of Mens Rea in International Criminal Law' (2004) 12 University of Miami International and Comparative Law Review 57, 69-70.

${ }^{82}$ Ibid.

${ }^{83}$ See Canadian Law Concerning Trials Of War Criminals By Military Courts, 4 United Nations War Commission: Law Reports of Trials of War Criminals 125 (1948) (Annex); Norwegian Law
} 
consider subsequent national trials which fleshed out many aspects of the legal principles at the centre of the Nuremberg international trials including the applicability of the defence of superior orders in more depth than the Nuremberg International Military Tribunal had done.

\section{Superior Orders defence-Putting Flesh to the Bone}

On 20 December 1945, the Allied Control Council promulgated CCL No. 10, which was to govern all further Nazi prosecutions in domestic courts. ${ }^{84}$ The law was the fulfilment of the vow made by the Allied Powers in the course of World War II to return war criminals so they could stand trial before tribunals in the territories in which their crimes had been committed. ${ }^{85}$ Many advances in enriching international jurisprudence and fleshing out the substantive content of international criminal law were made by post-World War II domestic tribunals in implementing the Nuremberg legacy. Literally thousands of trials were carried out in domestic tribunals in different countries and regions of the world subsequent to the Nuremberg and Tokyo international trials.

CCL No. 10 was closely modelled on the Nuremberg Charter. Like the Nuremberg Charter, it abrogated the act of State doctrine ${ }^{86}$ and rejected superior orders as a

Concerning Trials Of War Criminals, 3 United Nations War Commission: Law Reports of Trials of War Criminals 81, 85-6 (Annex I).

${ }^{84}$ Allied Control Council Law No. 10, Punishment of Persons Guilty of War Crimes, Crimes against Peace and against Humanity (20 December 1945), Official Gazette of the Control Council for Germany, No 3, Berlin, 31 January 1946 ('CCL No. 10').

85 'Declaration on German Atrocities, 30 October 1943', Documents on American Foreign Relations (1945) vol 6, 231, 232. 'Declaration on German Atrocities, 30 October 1943' in Council on Foreign Relations, Documents on American Foreign Relations (1945) vol 6, 231, 232.

${ }^{86}$ CCL No. 10, art 2, [4(a)]. 
defence. ${ }^{87}$ With regard to the defence of superior orders, CCL No. 10 in language essentially identical to Article 8 of the Nuremburg Charter, provided in Article II.4(b) that ' $[\mathrm{t}]$ he fact that any person acted pursuant to the order of his Government or of a superior does not free him from responsibility for a crime, but may be considered in mitigation' ${ }^{88}$ These trials not only perpetuated the Nuremberg legacy but also made a significant contribution to the corpus of international criminal law and enriched international jurisprudence.

(a) The American Proceedings Under Allied Control Council Law No. 10

The decisions of national tribunals under CCL No. 10 (especially the twelve decisions by the US Military Tribunals-USMT) applied and extended the Nuremberg principles regarding the development of the corpus of international criminal law. ${ }^{89}$ These trials made a substantial contribution by expressly reaffirming the principle of individual criminal responsibility. The 'moral test', which effectively modified Article 8 of the Nuremburg Charter by ameliorating its blanket rejection of superior orders as a defense, also affected CCL. No. 10 Article proceedings which required showing of duress as a necessary part of a successful defense of superior orders. ${ }^{90}$ The consideration of the 'moral choice' test is apparent in the Flick' ${ }^{91}$ and Farben ${ }^{92}$

\footnotetext{
${ }^{87}$ CCL No. 10, art 2, [4(a)].

${ }^{88}$ CCL No. 10, art 4(b).

${ }^{89}$ For the most complete discussion, see William A Zeck, 'Nuremberg: Proceedings Subsequent to Goering Et Al' (1948) 26 North Carolina Law Review 350.

${ }^{90}$ See Prosecutor v Erdemovic, Case No IT-92-22-A (Judgment of Appeals Chamber, separate opinion of McDonald and Vohrah JJ, 7 October 1997), [35] ('[a]s obedience to superior orders may be considered merely as a factual element in determining whether duress is made out on the facts, the absence of a superior order does not mean that duress as a defense must fail').

91 See (1952) VI Trials of War Criminals Before the Nuremberg Military Tribunal 1197-8 (commenting on the Flick case).

${ }^{92}$ See (1952) VIII Trials of War Criminals Before the Nuremberg Military Tribunals 1206-9 (commenting on Farben case).
} 
judgments while, in the High Command cases, the American tribunal noted that the law must allow a solider to assume that orders conform to international law. ${ }^{93}$

The superior orders clause was first interpreted by a three judge American panel in the Einsatzgruppen judgment. ${ }^{94}$ This related to the Einsatzgruppen killing squads which shadowed the Nazi troops as they swept across Russia and ruthlessly carried out the Fuhrer Order, which called for the summary execution of Jews, Gypsies, disabled, homeless, mentally challenged individuals and communist functionaries. ${ }^{95}$ At trial, Dr. Hans Gawlik, attorney for defendant Erich Naumann, the Chief of Einsatzgruppe B contended that following World War I, the Commission on Responsibility feared that defendants would mechanically invoke the superior orders defence and, as a result, recommended that the admissibility of the defense should be a matter of judicial discretion. The American Tribunal however stressed that soldiers are 'reasoning agent[s]' and are not mere mechanical machines who reflexively respond to orders. ${ }^{96}$ However, the Court clarified that to plead superior orders, an individual must demonstrate an 'excusable ignorance' of an order's 'illegal character'. ${ }^{97}$ The judgment established that the superior orders defense was available in those instances in which a defendant was able to demonstrate excusable ignorance concerning the illegality of an order and further, that the defence was available in mitigation in those instances in which a defendant involuntarily carried out a command.

\footnotetext{
${ }^{93}$ See (1950) XI Trials of War Criminals Before the Nuremberg Military Tribunals 511.

${ }^{94}$ See United States v. Ohlendorf (1950) IV Trials of War Criminals Before the Nurernberg Military Tribunals Under Control Council Law No. 10, 411.

${ }^{95}$ Ibid 412-6.

96 Ibid 470.

${ }^{97}$ Ibid 412-6.
} 
In the High Command Trial, Wilhelm von Leeb received the very light sentence of three years in prison, with the tribunal noting that there was much to be said in mitigation: '[t]he United States Military Tribunal specifically noted that this was a case for application of the excuse of superior orders not as a defense but as a factor in mitigation of punishment. ${ }^{98}$ The thrust of the High Command judgment was that a subordinate will not be deemed to possess the requisite criminal intent in the event that he was not aware of, and could not reasonably have been expected to have been aware of, the illegal character of a command. ${ }^{99}$ The Tribunal recognised that this rule compelled a commander to choose between possible domestic punishment for disobedience and sanction by the international community for committing a crime against the law of nations. ${ }^{100}$ Importantly,

[t]he Court minimized the significance of the earlier provisions of the British and American military manuals, noting that these were neither authoritative legislative nor judicial pronouncements; manuals at most may play an evidentiary role in determining the existence of a custom or practice. ${ }^{101}$

In the Hostages Case, the Court ruled that members of the armed forces are only bound to obey lawful orders and cannot escape criminal liability in those cases in which they comply with commands which violate international law and outrage fundamental concepts of justice. ${ }^{102}$ The Court asserted:

'If the act done pursuant to a superior's order be murder, the production of the order will not make it any less so. It may mitigate but it cannot justify the crime. We are of the view, however, that if the illegality of the order was not known to the inferior, and he could not reasonably have been expected to know of its illegality, no wrongful intent necessary to the commission of the crime exists and the inferior will be protected.' 103

\footnotetext{
${ }^{98}$ Schabas, above n 76, 487.

99 'Opening Statement for Defendant List' (1950) XI Trials of War Criminals Before the Nurernberg Military Tribunals Under Control Council Law No. 10, 1236.

${ }^{100}$ Ibid 1236-7.

101 Matthew R Lippman, 'Humanitarian Law: The Development and Scope of the Superior Orders Defense' (2001) 20 Penn State International Law Review 153, 194.

102 'Opening Statement for Defendant List' (1950) XI Trials of War Criminals Before the Nurernberg Military Tribunals Under Control Council Law No. 10, 862.

${ }^{103}$ United States $v$ Wilhelm List \& Others (The Hostage Cases) (1949) VIII Trials Of War Criminals Before The Nuerenberg Military Tribunal Under Control Council Law No. 10, 34, 50; see also United
} 
(b) The British Proceedings Under Allied Control Council Law No. 10

In the Trial of Max Wielen and 17 others ('The Stalag Luft III Case'), the Head of the Criminal Police in Breslau along with members of the SS were charged with executing fifty members of the Royal Air Force and other Allied forces. On the night of 24 March 1944, 80 officers of the Royal Air Force and other Allied Air Force had escaped from a prisoner of war camp - the Stalag Luft III—at Sagan, in Silesia through an underground tunnel. On 26 March the news of the escape reached Hitler at Berchtesgarten and after consultations with his chief lieutenants Goering, Keitel and Himmler, he gave the verbal order that 'more than half of the escapees' were to be shot. ${ }^{104}$ The defendants pleaded the defence of superior orders. Dismissing the defence, the British Military Court determined that the defendants must have been aware that the execution of the prisoners violated an unchallenged rule of warfare and outraged the general sentiments of humanity.

United Kingdom v Eck ('the Peleus Case') was another significant case, to address superior orders before a British CCL No. 10 Court. The case concerned an incident of 3 March 1944 in which a German submarine had torpedoed and sank the Greek freighter Peleus in the South Atlantic. The submarine then surfaced and strafed the survivors in their lifeboats in an attempt to kill the entire crew. Four members of the German submarine crew were convicted of following orders to fire upon the crew of the Peleus. The Judge Advocate instructed that there was no duty to obey an unlawful order. The fact that a rule of warfare was violated pursuant to the order of a

States v. Ohlendorf (1950) IV Trials of War Criminals Before the Nuerenberg Military Tribunals Under Control Council Law No. 10 411, 470-1.

104 Trial Of Willy Zuehlke, 14 United Nations War Commission: Law Reports of Trials of War Criminals 139, 149 (1949). 
belligerent government or military official did not deprive the act of its criminal character or confer immunity from punishment. The Judge Advocate recognised that combatants could not be expected to consult an international law text or academic specialist during the heat of battle. However, 'it must have been obvious to the most rudimentary intelligence that [the order to fire upon the crew] was not a lawful command, and that those who shot are not to be excused for doing it upon the ground of superior orders'. ${ }^{105}$ Significantly though, superior orders was viewed as a mitigating circumstance by the British Military Tribunal, and brought a reduced sentence of fifteen years' imprisonment. ${ }^{106}$

(c) In Sum

This section has dealt at length with the Nuremberg international trials and the subsequent national trials under the umbrella of CCL. No. 10. However this is not to disregard the international trials at Tokyo and the subsequent national trials in the Pacific. The reality is that the Nuremberg Trials were the centre point of the Allied criminal law trials and greatly overshadowed the Tokyo international trials which commenced in 1946 after the conclusion of the Nuremberg international trials and in the thick of ongoing CCL No. 10 trials. The most vibrant seam of case law that was to dominate and still dominates was that spawned by the Nuremberg International Military Tribunal and the various subsequent proceedings under the umbrella of CCL No. 10. It is noted that The Tokyo International Military Tribunal Charter's Article 6(b) which set the stage for the international trials, as well as Paragraph 16 of

\footnotetext{
${ }^{105}$ See United Kingdom v Eck et al (1947) 1 United Nations War Commission: Law Reports of Trials of War Criminals 1, 12.

${ }^{106}$ See United Kingdom v Eck et al (1947) 1 United Nations War Commission: Law Reports of Trials of War Criminals 1, 21.
} 
American Regulations Governing the Trial of War Criminals in the Pacific Area which set the stage for national trials, were similar to the Nuremberg IMT's Article 8. As happened at Nuremberg, the Tokyo tribunal rejected pleas of superior orders. ${ }^{107}$ The resulting national tribunals for prosecution of war crimes in the Pacific and the Mediterranean also employed similar procedural articles.

III POST-WORLD WAR II: A Wrong Is A WrONG

In 1962, the Israel Supreme Court convicted Adolf Eichmann. Eichmann had been an active participant in the 'Final Solution of the Jewish Question'. He had the responsibility of 'Transportation Administrator', which put him in charge of all the trains which would carry Jews to the Death Camps in the territory of occupied Poland. In this role he facilitated and managed the logistics of mass deportation of Jews to ghettos and death camps in the occupied East Europe. He was indicted on 15 criminal charges, including charges of crimes against humanity, crimes against the Jewish people and membership of an outlawed organisation. During the whole trial, Eichmann insisted that he was only 'following orders' - the same defense used by the Nazi war criminals during the 1945-1946 Nuremberg Trials. He explicitly declared that he had abdicated his conscience in order to follow the Fuhrerprinzip. Addressing the dominant 'manifestly illegal' standard in relation to the superior orders defence, the Court stated:

The distinguishing mark of a "manifestly unlawful order" should fly like a black flag above the order given, as a warning saying "Prohibited." Not formal unlawfulness, hidden or halfhidden, nor unlawfulness discernible only to the eyes of legal experts, is important here, but a flagrant and manifest breach of the law, definite and necessary unlawfulness appearing on the face of the order itself, the clearly criminal character of the acts ordered to be done, unlawfulness piercing the eye and revolting the heart, be the eye not blind nor the heart not

\footnotetext{
${ }^{107}$ In re Masuda et al, reprinted in Hersch Lauterpacht (ed), Annual Digest and Reports of Public International Law Cases (1951) 286.
} 
stony and corrupt, that is the measure of "manifest unlawfulness" required to release a soldier from the duty of obedience upon him and make him criminally responsible for his acts. ${ }^{108}$

In 1953, the legal standard of manifestly illegal orders was evident in the case of United States v Kinder. ${ }^{109}$ Kinder, an Air Force police officer, 'apprehended a Korean [national] in a bomb dump'. ${ }^{110} \mathrm{He}$ was later ordered and complied with the command of Air Police Officer George C. Schreiber to kill the prisoner. ${ }^{111}$ The Court Martial ruled that the content and context of the order to execute the Korean detainee was 'so obviously beyond the scope of authority' of Kinder's superior and 'so palpably illegal on its face as to admit of no doubt of its unlawfulness to a man of ordinary sense and understanding, 112

Two decades after Kinder, Lieutenant William Calley 'was convicted by a general court martial... of premeditated murder and... assault with intent to commit murder'. ${ }^{113}$ On 16 March 1968, Calley’s platoon swept through the hamlet of My Lai with an investigation later revealing that while in My Lai, Calley supervised and participated in the execution of hundreds of unarmed Vietnamese civilians. ${ }^{114}$ Calley's principle defense was that he acted in accordance with superior orders and lacked a criminal intent. ${ }^{115} \mathrm{He}$ contended that on five separate occasions his superior Captain Ernest Medina had ordered him to 'waste' the villagers. ${ }^{116}$ Medina, according to Calley, clearly commanded 'that under no circumstances would we let anyone get

\footnotetext{
${ }^{108}$ Attorney-General of the Government of Israel v. Eichmann (1962) 36 ILR 275, 277.

${ }^{109}$ United States $v$ Kinder (1953) 14 CMR 742.

${ }^{110}$ United States $v$ Kinder (1953) 14 CMR 742, 753.

111 United States $v$ Kinder (1953) 14 CMR 742, 755.

112 United States $v$ Kinder (1953) 14 CMR 742, 774.

113 United States $v$ Calley (1973) 46 CMR 1131, 1138.

${ }^{114}$ See United States v Calley (1973) 46 CMR 1131, 1173.

115 See United States v Calley (1973) 46 CMR 1131, 1180.

${ }^{116}$ See United States v Calley (1973) 46 CMR 1131, 1182.
} 
behind us, nor would we leave anything standing in these villages'. ${ }^{117}$ The Court of Military Review dismissed the defendant's argument that a subordinate should only be held liable in the event that he personally knew of an order's illegality. ${ }^{118}$ The Court of Military Appeals affirmed that the 'man of ordinary sense and understanding' under the circumstances would have been aware of the illegality of the order. ${ }^{119}$ However, in a strong dissent, Judge William H. Darden argued that adherence to superior orders was an essential ingredient of discipline and should constitute a defense unless the commands would be recognised as illegal by persons of minimal intelligence and experience. ${ }^{120}$

In sum, the author avers the defence of superior orders applied to all international crimes. As The My Lai massacre amounted to a systematic massacre that met the benchmark of a crime against humanity and the defence of superior orders was put forth by Calley, entertained but dismissed for the reasons outlined above. This author's position is further buttressed by the 1990s Canadian Case of Regina v Finta. The case noted the applicability of the superior orders defence. Justice Cory, speaking for the majority, stated that 'the mens rea requirement of both crimes against humanity and war crimes would be met if it were established that the accused was willfully blind to the facts or circumstances that would bring his or her actions within the provisions of these offences'. ${ }^{121}$ The case importantly bolsters a stance that was to be departed from by the Rome Statute four years later when it set a dichotomy in allowing the defence for war crimes and precluding it for crimes against humanity and genocide.

\footnotetext{
${ }^{117}$ See United States v Calley (1973) 46 CMR 1131, 1181-2.

${ }^{118}$ See United States v Calley (1973) 46 CMR 1131, 1184.

${ }^{119}$ See United States v Calley (1973) 46 CMR 1131, 1184.

${ }^{120}$ See United States v Calley (1973) 46 CMR 1131, 1196.

${ }^{121} R$ v Finta [1994] 1 SCR 701, 819.
} 
The end of the Cold War, which paralysed the United Nations from its inception, was a cause for celebration and hope. Following the historic Security Council Summit Meeting of January 1992, the then Secretary-General of the United Nations, Boutros Boutros-Ghali, spoke of a growing conviction

among nations large and small, that an opportunity has been regained to achieve the great objectives of the UN Charter - a United Nations capable of maintaining international peace and security, of securing justice and human rights and of promoting, in the words of the Charter, "social progress and better standards of life in larger freedom". 122

Even as this optimistic mission statement was being made, the Balkans had erupted into a theatre of war and Rwanda's genocidal conflagration was in the making. These events were to lead to the establishment of two ad hoc international criminal tribunals for the former Yugoslavia and Rwanda and create the impetus for the establishment of the International Criminal Court in 1998 during the Rome Conference of the same year.

The statutes of both the ICTY and ICTR explicitly exclude the defence of 'superior orders' from the litigation part of the trial. ${ }^{123}$ The Statutes provide in almost identical terms that reliance by an accused person on an order of a Government or of a superior shall not relieve him or her of criminal responsibility, but may be considered in mitigation of punishment if the Tribunal determines that justice so requires. ${ }^{124}$ Thus, although not strictly a defence, obedience to orders can be a relevant and admissible

\footnotetext{
${ }^{122}$ Report of the Secretary General on the Work of the Organization, UN GAOR, $47^{\text {th }}$ sess, UN Doc A/47/277, S/24111 (1992).

${ }^{123}$ See Statute of the International Criminal Tribunal for the Former Yugoslavia ('ICTY Statute'), art 7(4); International Criminal Tribunal for Rwanda Statute ('ICTR Statute') art 6(4). As with the Nuremberg trials, the courts in Yugoslavia and Rwanda consider the 'superior orders defense' only as a mitigating factor in the sentencing stage.

${ }^{124}$ ICTY Statute, art 7(4); ICTR Statute, art 6(4).
} 
fact. This articulation of the superior orders defense under which a subordinate who committed a crime can escape responsibility because s/he was following the orders of his/her superior enshrines and cements the position of the Nuremberg Charter. ${ }^{125}$ The position further buttresses the trend in international law towards absolutely discarding superior orders as a ground of justification in cases involving the commission of international crimes. $^{126}$

In the first case since World War II before an international criminal tribunal, the ICTFY in Prosecutor v Erdemovic sentenced a Croat infantryman, Drazen Erdemovic, to ten years. The issue of superior orders was central to the sentencing debate. The Trial Chamber noted that the provisions in the ICTFY Statute dealing with superior orders are 'practically identical' to those applicable at Nuremberg. ${ }^{127}$ In this regard the international criminal tribunal noted that superior orders is expressly excluded as a defense. The Trial Chamber noted that the Nuremberg International Military Tribunal had not accepted superior orders as a mitigating factor in the case of the major war criminals, but signalled its willingness to adopt a more forgiving position based on the position of the subordinate. ${ }^{128}$ In the specifics of Erdemovic, the Trial Chamber accepted as relevant the fact that he had followed orders and held a subordinate position in the military hierarchy. ${ }^{129}$ McDonald and Yohrah, JJ. endorsed the following proposition:

\footnotetext{
${ }^{125}$ Nuremberg Charter, opened for signature 8 August 1945, 82 UNTS 280, art 8 (entered into force 8 August 1945): 'The fact that the defendant acted pursuant to orders of his Government or of a superior shall not free him from responsibility, but may be considered in mitigation of punishment, if the Tribunal determines that justice so requires.'

${ }^{126}$ Van der Vyver, above n 81, 77.

${ }^{127}$ See Prosecutor v Erdemovic, Case No IT-96-22-T (Sentencing Judgment of Trial Chamber I, 29 November 1996), [48].

${ }^{128}$ See Prosecutor v Erdemovic, Case No IT-96-22-T (Sentencing Judgment of Trial Chamber I, 29 November 1996), [53].

${ }^{129}$ See Prosecutor v Erdemovic, Case No IT-96-22-T (Sentencing Judgment of Trial Chamber I, 29 November 1996), [92]-[95].
} 
We subscribe to the view that obedience to superior orders does not amount to a defence per se but is a factual element which may be taken into consideration in conjunction with other circumstances of the case in assessing whether the defences of duress or mistake of fact are made out. $^{130}$

The position in Erdemovic was symptomatic of several other trials at the ICTY and the ICTR. The ad hoc international criminal tribunals proved amenable to the defense of superior orders despite the contrary language of their Statutes in cases that indicated that the defendant acted in obedience to a superior under circumstances of duress and/or coercion. ${ }^{131}$ The emerging standard at the ad hoc international criminal tribunals is that 'evidence of having received orders from superiors, though not a complete defense, is relevant and admissible to the question of whether the soldier labored under duress when performing the command'. ${ }^{132}$ This position by the tribunals is the dominant and consistent approach and negates any further sustained analysis of the case law of the ad hoc international criminal tribunals considering that the Article has already extensively canvassed the case law of the Nuremberg/Tokyo International Military Tribunals, which is reflected and echoed in the ad hoc international criminal tribunals. In sum, a synthesis of the case law of the ad hoc international criminal tribunals (as exemplified in the Erdemovic Trial) points to a cementing of the international law standard (noted in Part II above) that discards superior orders as a defence but allows it only as a mitigating factor.

The seeming linear progression towards a bright line legal principle in international law regarding the defence that had been propagated eight decades earlier at Versailles

\footnotetext{
${ }^{130}$ Prosecutor v Erdemovic, Case No IT-92-22-A (Judgment of Appeals Chamber, separate opinion of McDonald and Vohrah JJ, 7 October 1997), [34].

${ }^{131}$ Drazen Erdemovic, Case No IT-96-22-T at 9 ('While the complete defence based on moral duress and/or a state of necessity stemming from superior orders is not ruled out absolutely, its conditions of application are particularly strict.').

${ }^{132}$ Mark J Osiel, Obeying Orders: Atrocity, Military Discipline, and the Law of War (1999) 43.
} 
at the end of World War I was however to receive a major jolt in 1998. In a serious shake up of the international standard, the Rome Statute became the first multilateral treaty dealing with international penal process to recognise the defense of superior orders (even though in a diluted form). ${ }^{133}$ The Statute in a departure from prevailing legal provisions encapsulated in the Nuremberg Charter and the Statutes of the ad hoc international criminal tribunals allows the defense of superior orders upon certain conditions being present: the subordinate was under a legal obligation to obey orders, the subordinate did not know the order was unlawful, and the order was not manifestly unlawful. ${ }^{134}$ However the statute explicitly specifies that orders to commit genocide or crimes against humanity are illegal as a matter of law. ${ }^{135}$

\section{B The Rome Statute: From The 1990s Into The $21^{\text {st }}$ Century-The Past In The Present? Where Is The Future}

During the Rome Conference in the summer of 1998 that lead to the establishment of the ICC, it was clear that some States were keen to retain the virtues of military discipline through a recognition of the superior orders as a complete defence. This position was spearheaded by the American delegation which in a reversible of its support for discarding the defence in the negotiations for the Nuremberg Charter sought to convince others that superior orders ought to be accepted as a valid defence under the rules of international law (and simply as a mitigating factor). The Americans argued that the position taken by the Nuremberg International Military Tribunal in precluding the defence ought to be seen as an aberration that was

\footnotetext{
${ }^{133}$ Statute of the International Criminal Court, UN Doc A/Conf.183/9, opened for signature 17 July 1998 (entered into force 1 July 2002), reprinted in 37 ILM 1002 (1998) ('Rome Statute').

${ }^{134}$ Rome Statute, art 33(1).

${ }^{135}$ Rome Statute, art 33(2).
} 
contingent upon the special circumstances that prevailed in Nazi Germany. ${ }^{136}$ In essence the Americans sought to resurrect the pre-World War II Anglo-American position. Interestingly, among the many delegations that opposed the American view was the United Kingdom. ${ }^{137}$

The American position driven strongly by the muscle of its delegation - the largestand backed by the formidable political muscle of the world's superpower was too strong to be swept aside despite vigorous objection. Further impetus was added when some major players (including China, India, Nigeria and Russian) joined hands with the United States in insisting on an absolute threshold. To achieve consensus, compromises had to made. A visible sign of this method is the apparent threshold introduced in the forefront of Article 8 defining war crimes. The first paragraph of Article 8 orients the Court specifically towards planned or widespread commission of war crimes. ${ }^{138}$ This is coupled with a more radical move enumerating permissible defences in Article 33. The Article in responding to the two divergent and opposing views - absolute liability or non-absolute liability—seeks to strike a balance. It provides as follows:

1. The fact that a crime within the jurisdiction of the Court has been committed by a person pursuant to an order of a Government or of a superior, whether military or civilian, shall not relieve that person of criminal responsibility unless:

(a) The person was under a legal obligation to obey orders of the Government or the superior in question;

(b) The person did not know that the order was unlawful; and

(c) The order was not manifestly unlawful.

2. For the purposes of this article, orders to commit genocide or crimes against humanity are manifestly unlawful.

\footnotetext{
${ }^{136}$ K Ambos, 'General Principles of Criminal Law in the Rome Statute' (1999) 10 Criminal Law Forum 1, 30-1.

137 These countries argued that a subordinate who has been instructed to perform an act which constitutes a crime within the jurisdiction of the ICC should not be excused but could in appropriate circumstances raise the defense of mistake or duress.

${ }^{138}$ Rome Statute, art 8(1).
} 
Article 33 was specifically drafted to cover the category of war crimes. ${ }^{139}$ As Paragraph 2 provides, it clearly and automatically excludes the relevance of paragraph 1 for crimes against humanity and genocide. ${ }^{140}$ Indeed, one of the cumulative requirements for the accused being relieved of criminal responsibility-dolus eventualis - is missing due to the very nature of the crimes. John D. Van der Vyver notes that in general an analysis of this provision shows that the Rome Statute does not recognise superior orders as an objective ground of justification at all, because an order to commit an international crime is in itself unlawful. ${ }^{141}$ However, the three requirements in Article 33 apply cumulatively, and successfully raising the defence of superior orders therefore depends in the final analysis on the 'mental' component of that defense (guilty knowledge). The Rome Statute thus accepts superior orders as a defence provided the order was executed by a subordinate in circumstances that excludes guilty knowledge and therefore negates the element of fault a situation that may be possible in the case of war crimes where responding to orders is central and may in the author's position be a plausible excuse in isolated incidents, scenarios of which the author will paint below. In a further shift towards creating a dichotomy between war crimes and the other two international crimes (crimes against humanity and genocide), Part Three on general principles of criminal law contains four grounds for excluding criminal responsibility: mental disease or defect, intoxication, defensive action and duress. ${ }^{142}$ It however admits of an additional ground defence of property which is limited to the sole category of war crimes. ${ }^{143}$

\footnotetext{
${ }^{139}$ Rome Statute, art 33(1).

${ }^{140}$ Rome Statute, art 33(2).

${ }^{141}$ Van der Vyver, above n 81, 80-1.

${ }^{142}$ Rome Statute, art 31(1).

${ }^{143}$ Rome Statute, art 31(1)(c).
} 
The author avers that a key reason that the Rome Statute deals separately with war crimes is premised on the special instance of crimes against humanity and genocidethe mens rea. To elaborate this statement, let us begin with a look at Article 1 of the Rome Statute. In this Article, the Statute upholds the principle of no liability without fault to the letter: Unless otherwise provided, a person shall be criminally responsible and liable for punishment for a crime within the jurisdiction of the Court only if the material elements are committed with intent and knowledge. ${ }^{144}$ The conjunctive requirement of intent and knowledge encapsulated in Article 1 is further defined in Article 30(1) of the Rome Statute. This Article makes criminal responsibility for any of the crimes within the subject-matter jurisdiction of the Court conditional upon the material elements of the crime concerned having been committed 'with intent and knowledge'. Paragraph 2 of Article 30 defines intent as follows:

For the purposes of this article, a person has intent where:

(a) In relation to conduct, that person means to engage in the conduct;

(b) In relation to a consequence, that person means to cause that consequence or is aware that it will occur in the ordinary course of events.

Synthesising the foregoing provisions, it is evident that the Rome Statute recognises mistake of law as a ground of exculpation in all cases where the perpetrator, because of the mistake, lacks mens rea. If the perpetrator honestly believes that his/her act would fall within the confines of circumstances that would legally deprive the act of criminality, then it cannot be said that s/he intentionally committed the crime. Guilty knowledge is an essential component of crimes against humanity and genocide but the thinking in precluding superior orders arguably was based on the fact the very nature and threshold indicia for these two crimes (systematic and widespread) excludes all doubts that might be entertained in assessing intent and knowledge.

${ }^{144}$ Rome Statute, art 30(1). 
Carrying forth the argument, 'knowledge' is defined in the Rome Statute as 'awareness that a circumstance exists or a consequence will occur in the ordinary course of events'. ${ }^{145}$ This definition covers dolus directus, dolus indirectus and dolus eventualis. Therefore, with regard to crimes against humanity and genocide 'intent' in relation to conduct, as defined in the Rome Statute, transcends dolus directus and dolus indirectus to encompass dolus eventualis. The latter excludes the provision requiring intent and knowledge considering that intentional killing of human beings encompasses dolus eventualis and falls within the purview of the intent and knowledge test that covers crimes against humanity and genocide and the particular consequence as an essential component of the crimes concerned.

To elaborate on this, let us consider four brief scenarios. A soldier may mistakenly fire a missile into a civilian shelter owing to faulty intelligence or target marking or bomb a rail bridge over a river unaware that a train with civilians is approaching. However, a soldier lining up unarmed women and children for execution or loading up unarmed civilians onto cattle trucks for transportation to a detention camp is a different story. Michael Bothe in a position that challenges this scenarios set out by the author argues that the repetition of words denoting intent in the Rome Statute in the definitions of particular war crimes denotes that 'not only the actual conduct (eg the dropping of a bomb), but also the consequences (eg hitting a civilian object) must be covered by the intent'. ${ }^{146}$ The author disagrees, as painted above crimes against humanity and genocide are special intent crimes, while many war crimes are not necessarily so. A soldier's acts are to be judged in the context of the facts and knowledge that s/he had at the time of the act and which s/he genuinely relied on (the

\footnotetext{
${ }^{145}$ Rome Statute, art 30(3).

${ }^{146}$ Michael Bothe, 'War Crimes' in A Cassese et al (eds), The Rome Statute Of The International Criminal Court: A Commentary (2002) 370, 389.
} 
scenario of the civilian shelter and rail bridge) not the facts emerging thereafter. However as can be seen through the scenario of the unarmed women and children and the cattle truck transportation) no justification precedent or subsequent too can amount to a mistake of fact.. This position finds support in Professor Leila N. Sadat's riposte to Bothe which dismisses Bothe's assertion as incorrect. Responding to Bothe's scenarios, Sadat asserts that no one of the war crimes listed by Bothe are special intent crimes, and the conclusion seems inevitable that repeating the element of intent in these cases add nothing to the general requirement of fault. ${ }^{147}$ Considering that crimes against humanity and genocide are special intent crimes no one claiming ignorantia juris in respect of these crimes can be taken seriously considering that they require a distinct manifestation of dolus specialis and dolus directus. This was summed up in an erudite fashion in the Eichmann Trial.

In targeting the superior orders defence as applicable to war crimes and not to crimes against humanity and genocide, the Rome Statute seems to adopt a pragmatic approach. On one hand, acting upon superior orders to commit a crime within the jurisdiction of the ICC is no excuse, because the order to commit any of those crimes is in itself unlawful and must be disobeyed by the subordinate. However, there is the centuries old exception to the rule which has championed the position that: if the perpetrator of the crime acted upon the orders of his or her government, or of a military or civilian superior, while being unaware that the order was unlawful, the subordinate will not be responsible for the offence, provided he or she was under a legal obligation (which soldiers are under as a matter of law) to obey orders of the government or of the concerned military or civilian superior, and the order was not

\footnotetext{
${ }^{147}$ Leila Nadya Sadat, The International Criminal Court And The Transformation Of International Law: Justice For The New Millennium (2002) 162, 210-1.
} 
manifestly unlawful. ${ }^{148}$ In light of the threshold requirements set by the Rome Statute for crimes against humanity, Cassesse observes that 'the requisite mens rea must include the awareness that the individual criminal act is part of a widespread or systematic attack on a civilian population'. ${ }^{149}$ The element of fault prescribed for the crime of genocide is a variety of dolus specialis and as such qualifies the acts through which genocide is committed: the act must be committed 'with intent to destroy, in whole or in part, a national, ethnical, racial or religious group, as such' ${ }^{150}$

In sum, the distinction made in the Rome Statute in regard to the mental element pertaining to conduct and the mental element pertaining to a consequence of the conduct seems to have been the rallying point around which the dichotomy between war crimes on war hand and crimes against humanity and genocide on the other were differently treated. Thus the nature of crimes against humanity and genocide means the essential element of knowledge (being aware that a circumstance exists or a consequence will occur in the ordinary course of events) ${ }^{151}$ does not explicate dolus directus and dolus indirectus but rather should be synthesised by encompassing the dolus eventualis standard.

\footnotetext{
149 A Cassese, 'Crimes against Humanity' in A Cassese et al (eds), The Rome Statute Of The International Criminal Court: A Commentary (2002) 353, 373.

${ }^{150}$ See Prosecutor v Jean Kambanda, Case No ICTR-97-23-S (Judgment and Sentence, 4 September 1998), [16]; Prosecutor v Radislav Krstic, Case No IT-98-33-T, (Judgment of Trial Chamber I, 2 August 2001), [571].

${ }^{151}$ Rome Statute, art 30(3).
} 


\section{CONCLUSION}

More than six decades ago Kelsen decried having combatants fighting for survival being placed in the position of calibrating the legal status of commands. ${ }^{152}$ From the foregoing discussion and analysis, the trend has been that international criminal tribunals courts prohibit a defence of superior orders per se, but typically allow the fact that a subordinate followed a superior's order to serve as a mitigating factor for sentencing purposes. ${ }^{153}$ But even this linear development was derailed with the adoption of the Rome Statute which allows a diluted form of the standard but only for war crimes.

The position regarding the defence of superior orders is no clearer in the $21^{\text {st }}$ century and its legal parameters remain opaque. The dominant international legal instruments the statutes of the two ad hoc international criminal tribunals on the one hand and the Rome Statute on the other, continue to encapsulate an ambivalence that leaves the exact status of the defence open and fluid. In sum, it can be said that a subordinate can rely on a superior order that culminated in the commission of a crime, 'but then only (i) if the subordinate knew or should have known that the order was illegal, or (ii) the order was manifestly illegal. This view also has some support as being the norm that applies in international law. ${ }^{154}$ It is evident that the question of whether a rule of warfare violated in pursuance of an order of a belligerent commander deprived the act in question of its character as a war crime or whether it conferred upon the perpetrator immunity from punishment is still the subject of serious but inclusive debate. To date

\footnotetext{
${ }^{152}$ Kelsen, above n 50, 556.

${ }^{153}$ See eg In Re Von Leeb (1948) XI Trials of War Criminals Before the Nuernberg Military Tribunals Under Control Council Law No. 10, 511, 533.

${ }^{154}$ Van der Vyver, above n 81, 78.
} 
the concept remains the subject of different national and international legal dimensions and scholarly with no clear position legally and in case law as to what the consensual legal principle is. ${ }^{155}$

${ }^{155}$ See Oppenheim, above n 45, 453-4. 